\title{
PENGARUH KOMPETENSI, MOTIVASI DAN BUDAYA PERUSAHAAN TERHADAP KINERJA KARYAWAN PADA UPTD PUSKESMAS PURBOLINGGO LAMPUNG TIMUR
}

\author{
Titin Rosdyanti ${ }^{1}$, Suwarto ${ }^{2}$ \\ Universitas Muhammadiyah Metro \\ titinrosdyanti0@gmail.com¹,wartok_umm@yahoo.co.id²
}

\begin{abstract}
ABSTRAK
Posisi dan peran PNS sebagai unsur aparatur negara sangat penting yaitu bertugas melaksanakan pelayanan dengan baik. Bentuk kinerja pelayanan kepada masyarakat adalah melalui upaya penyediaan pelayanan kesehatan kepada masyarakat khususnya di Puskesmas. Beberapa faktor yang berhubungan dengan kinerja karyawan adalah kompetensi, motivasi dan budaya organisasi. Tujuan penelitian ini adalah untuk mengetahui pengaruh kompetensi, motivasi dan budaya organisasi terhadap kinerja karyawan di UPTD Puskesmas Purbolinggo, Lampung Timur. Metode yang digunakan dalam penelitian ini adalah metode survei explanatory. Jenis penelitian ini adalah penelitian kuantitatif dengan objek penelitian adalah kompetensi, motivasi, budaya organisasi dan kinerja karyawan. Populasi dalam penelitian ini adalah karyawan di Puskesmas Purbolinggo dengan total sampel 52 responden. Teknik pengumpulan data menggunakan kuesioner. Alat analisis yang digunakan adalah dengan menggunakan analisis kualitas data dan analisis regresi linier berganda. Hasil penelitian menunjukkan bahwa kompetensi, motivasi dan budaya organisasi berpengaruh baik secara parsial maupun simultan pada kinerja karyawan. Melihat signifikansi yang diperoleh, variabel yang paling berpengaruh pada kinerja karyawan adalah variabel budaya organisasi.
\end{abstract}

Keywords: Kompetensi, Motivasi, Budaya Organisasi, Kinerja Karyawan

\begin{abstract}
Position and role of Civil Servants as elements of the state apparatus is important tasked with carrying out services well. The form of service performance to the community is through efforts to provide health services to the community especially at the Health Center. Several factors related to employee performance are competency, motivation and organizational culture. The purpose of this study was to determine the effect of competence, motivation and organizational culture on employee performance at the UPTD Puskesmas Purbolinggo, East Lampung. The method used in this research is the explanatory survey method. This type of research is quantitative research with the object of research are competence, motivation, organizational culture and employee performance. The study population was employees at the Puskesmas Purbolinggo with a total sample of 52 respondents. Data collection techniques using questionnaires. The analytical tool used is to use data quality analysis and multiple linear regression analysis. The results showed that competency, motivation and organizational culture influence both partially and simultaneously on employee performance. Seeing the significance obtained, the most influential variable on employee performance is the organizational culture variable.
\end{abstract}

Keywords: Competence, Motivation, Organizational Culture, Employee Performance

\section{PENDAHULUAN}

Sumber daya manusia dalam organisasi publik dikenal dengan sebutan pegawai. Aparatur Sipil Negara (ASN) atau dahulu dikenal sebagai Pegawai Negeri Sipil (PNS) adalah 
setiap warga negara Republik Indonesia yang telah memenuhi syarat yang ditentukan, diangkat oleh pejabat yang berwenang dan diserahi tugas dalam suatu jabatan, atau diserahi tugas negara lainnya, dan digaji berdasarkan peraturan perundang-undangan yang berlaku. Aparatur Sipil Negara (ASN) berkedudukan sebagai unsur aparatur Negara yang bertugas untuk memberikan pelayanan kepada masyarakat secara profesional, jujur, adil, dan merata dalam penyelenggaraan tugas negara, pemerintahan dan pembangunan.

Kedudukan dan peranan Pegawai Negeri Sipil sebagai unsur aparatur negara yang bertugas sebagai abdi masyarakat harus menyelenggarakan pelayanan secara baik kepada masyarakat dengan dilandasi kesetiaan dan ketaatan kepada Pancasila dan Undang-Undang Dasar Untuk dapat melaksanakan tugas dengan baik, maka pembinaan pegawai diarahkan untuk meningkatkan kualitas sumber daya manusia agar memiliki sikap dan perilaku yang dapat memberikan pelayanan sesuai tuntutan perkembangan masyarakat. Untuk itu sangat dibutuhkan pegawai yang memiliki kinerja yang tinggi dalam melaksanakan tugasnya.

Kinerja pegawai merupakan suatu hal yang sangat penting dalam upaya organisasi untuk mencapai tujuannya. Salah satu hal yang harus diperhatikan dalam pelaksanaan pekerjaan yaitu tercapainya kinerja yang baik, sesuai dengan standar kinerja yang diterapkan dan yang diinginkan organisasi, dan sesuai dengan visi dan misi organisasi. Namun, agar semua pegawai dapat mewujudkan kinerja yang diinginkan, banyak faktor yang mungkin mempengaruhi kinerja pegawai dalam melaksanakan tugas, seperti kompetensi individu, motivasi kerja dan budaya organisasi dan lain sebagainya. Dengan demikian dapat dikatakan bahwa kinerja adalah prestasi seseorang baik kuantitas dan kualitas karena dalam melaksanakan pekerjaan secara maksimal dengan memanfaatkan sumber daya yang ada dalam periode tertentu.

Ada banyak indikator yang dapat digunakan untuk menilai kinerja pegawai dalam melaksanakan tugas, salah satunya adalah dengan membandingkan realisasi ketercapaian pekerjaan dengan target yang sudah disusun. Salah satu dari sekian banyak bentuk perhatian terhadap kinerja pelayanan kesehatan terhadap masyarakat adalah melalui upaya pelayanan kesehatan khususnya Puskemas. Berdasarkan UndangUndang no 36 tahun 2009 tentang Kesehatan dikatakan bahwa Puskesmas merupakan pionir pemerintah dalam memberikan pelayanan kesehatan terhadap masyarakat, puskesmas adalah unit pelaksana teknis dinas kesehatan kabupaten/kota yang bertanggung jawab menyelenggarakan pembangunan kesehatan di suatu wilayah kerja. Puskesmas sebagai unit pelaksana Dinas Kesehatan merupakan penanggung jawab penyelenggara upaya kesehatan untuk jenjang pertama di wilayah kerjanya masing-masing dalam memberikan pelayanan prima bagi masyarakat, maka untuk mencapai keberhasilan tersebut diselenggarakan berbagai upaya kesehatan secara menyeluruh, berjenjang, dan terpadu.

Berdasarkan kenyataan yang ditemukan pada sebagian puskesmas yang ada di Indonesia yaitu kinerja pegawai terindikasi masih kurang maksimal. Hal ini dapat dilihat dari realisasi laporan pencapaian kinerja yang belum mencapai angka $100 \%$. Hal ini tentu tidak bisa dilepaskan dari rendahnya kinerja pegawai. Selanjutnya juga terlihat bahwa realisasi pada masing-masing bagian masih jauh dari yang ditargetkan.

Permasalahan lainnya terlihat 
yaitu sebagian pegawai yang tidak dapat menyelesaikan pekerjaan tepat pada waktunya, sehingga terdapat antrian yang cukup panjang di puskesmas dan sebahagiannya juga kurang memahami dan mengikuti instruksi yang diberikan oleh pimpinan. Sebagian pegawai kurang mempunyai inisiatif dalam bekerja, diduga faktor yang berkemungkinan paling mempengaruhi kinerja pegawai adalah kompetensi individu, motivasi kerja dan budaya organisasi. Berkaitan dengan hal tersebut, dalam penelitian ini akan dibahas tiga faktor yang diidentifikasi mempengaruhi kinerja pegawai yaitu kompetensi individu, motivasi kerja dan budaya organisasi yang mungkin mempengaruhi kinerja pegawai.

Kompetensi adalah suatu

kemampuan untuk melaksanakan atau melakukan suatu pekerjaan yang dilandasi atas keterampilan dan pengetahuan serta didukung oleh sikap kerja yang dituntut oleh pekerjaan tersebut. Apabila kompetensinya baik, maka kinerja pun akan meningkat. Kompetensi berpengaruh positif dan signifikan secara langsung terhadap kinerja karyawan.

Faktor berikutnya yang diidentifikasikan berpengaruh terhadap kinerja karyawan adalah motivasi kerja. Siagian (2008) menyatakan motivasi adalah daya pendorong yang mengakibatkan seseorang anggota organisasi mau dan rela mengerahkan kemampuan dalam bentuk keahlian atau keterampilan, tenaga dan waktunya untuk menyelenggarakan berbagai kegiatan yang menjadi tanggung jawabnya dan menunaikan kewajibannya dalam rangka pencapaian tujuan dan berbagai sasaran organisasi yang telah ditentukan. Untuk itu, organisasi perlu untuk mengetahui apa yang menjadi motivasi para karyawannya, sebab faktor tersebut menjadi salah satu faktor yang menentukan jalan tidaknya pekerjaan dari visi dan misi yang dijabarkan dalam pencapaian kinerja karyawan dan tujuan organisasi secara keseluruhan.

Faktor lainnya yang diidentifikasikan berpengaruh pada kinerja adalah budaya organisasi. Budaya organisasi adalah suatu sistem nilai yang diperoleh dan dikembangkan oleh organisasi meliputi pola kebiasaan dan cara berperilaku, aturan yang digunakan, pedoman dalam berfikir dan bertindak, dalam mencapai tujuan organisasi. Dengan budaya organisasi yang baik maka jalannya perusahaan akan berjalan dengan baik dimana pegawai akan menjalankan tugasnya sesuai dengan apa yang telah perusahaan tentukan guna mencapai apa yang menjadi tujuan dari perusahaan tersebut.

\section{A. Tujuan Penelitian}

Adapun tujuan dari penelitian ini adalah:

1. Untuk mengetahui pengaruh kompetensi terhadap kinerja pegawai.

2. Untuk mengetahui pengaruh motivasi terhadap kinerja pegawai.

3. Untuk mengetahui pengaruh budaya organisasi terhadap kinerja pegawai.

4. Untuk mengetahui pengaruh kompetensi, motivasi dan budaya organisasi secara bersama-sama terhadap kinerja pegawai.

\section{B. Manajemen Sumber Daya Manusia}

Manajemen sumber daya manusia adalah suatu proses menangani berbagai masalah pada ruang lingkup pegawai, pegawai, buruh, manajer dan tenaga kerja lainnya untuk dapat menunjang aktifitas organisasi atau perusahaan demi mencapai tujuan yang telah ditentukan. Tujuan manajemen 
personalia berhubungan dengan tujuan perusahaan secara umum. Hal ini dikarenakan manajemen perusahaan berusaha untuk menimbulkan efisiensi dalam bidang tenaga kerja sebagai efisiensi keuntungan dan kontinuitas.

\section{Kompetensi}

Kompetensi adalah potensi pegawai dalam melaksanakan tugas atau pekerjaan, efektifitas kerja individu, kepribadian dan pengetahuan, serta yang meliputi motif, karakter, konsep diri, pengetahuan dan ketrampilan dari pegawai tersebut perilaku yang diperlukan dalam pelaksanaan tugas jabatannya.

\section{Motivasi}

Motivasi disini adalah dorongan dan keinginan, sehingga ia melakukan sesuatu kegiatan atau pekerjaan dengan memberikan yang terbaik demi tercapainya tujuan yang diinginkan. beberapa indikator yang dapat mendorong timbulnya diantaranya gaji, tunjangan, keselamatan kerja, penghargaan dan pujian, sistem pengkariran, hubungan dengan rekan kerja dan pengembangan diri.

\section{E. Budaya Organisasi}

Budaya organisasi adalah suatu sistem nilai yang diperoleh dan dikembangkan oleh organisasi meliputi pola kebiasaan dan cara berperilaku, aturan yang digunakan, pedoman dalam berfikir dan bertindak, dalam mencapai tujuan organisasi.

\section{F. Kinerja Pegawai}

Kinerja pegawai merupakan hasil yang dapat dicapai atau ditunjukan oleh seseorang didalam pelaksanaan tugas pekerjaan, dapat melaksanakan pekerjaan dengan baik, mencapai standar kerja, integritas pegawai, loyalitas, kepribadian dan tanggung jawab.

\section{METODE PENELITIAN}

Jenis penelitian adalah penelitian analisis kuantitatif dengan tujuan untuk menguji hipotesis yang telah ditetapkan. Penelitian analitik kuantitatif adalah penelitian dengan memperoleh data yang berbentuk angka atau data kualitatif yang diangkakan.

Penelitian dilaksanakan di UPTD Puskesmas Purbolinggo Lampung Timur. Pada penelitian ini variabel yang diteliti yaitu kompetensi, motivasi dan budaya organisasi dan kinerja pegawai, dengan bentuk hubungan ketiga variabel tersebut adalah sebab akibat (klausal).

Anggota populasi yang diambil sebagai sampel sebanyak 52 orang sebagai responden penelitian. Dalam penelitian ini sampel diambil secara keseluruhan dengan tehnik total sampling.

Metode yang digunakan dalam penelitian ini adalah metode explanatory survey yaitu metode yang bertujuan untuk menguji hipotesis dalam bentuk hubungan antar variabel. Teknik analisis data yang digunakan dalam penelitian ini yaitu regresi linier berganda yang diolah menggunakan bantuan program SPSS.

III. HASIL DAN PEMBAHASAN

A. Hasil Penelitian

1. Kompetensi

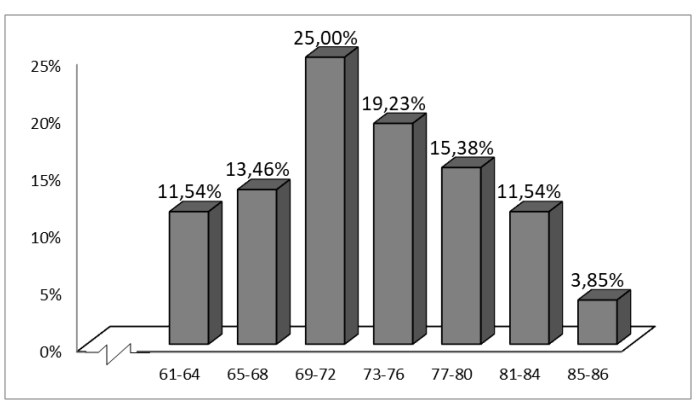


Distribusi frekuensi skor tertinggi pada skor $69-72$ sebesar $25 \%$.

2. Motivasi

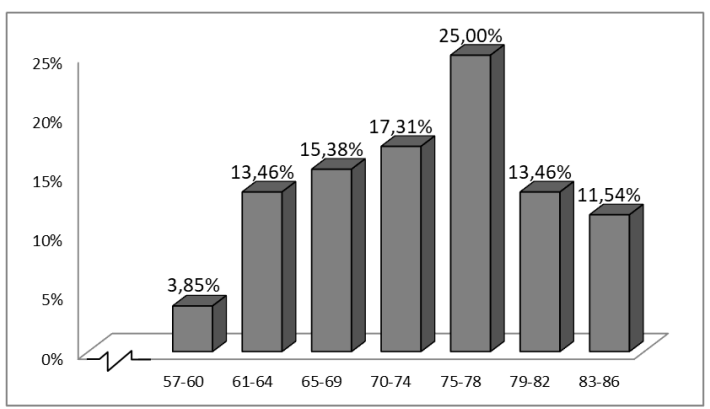

Distribusi frekuensi hasil tertinggi pada skor $75-78$ sebesar $24 \%$

3. Budaya Organisasi

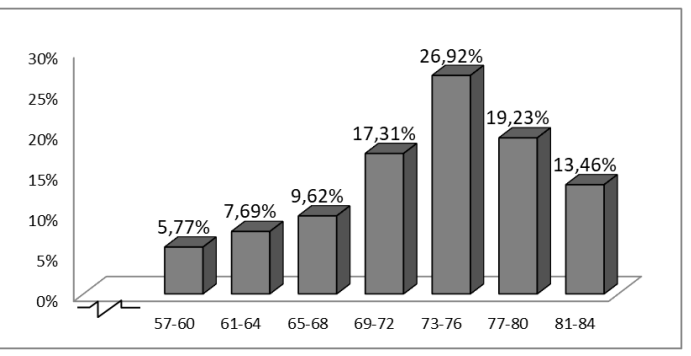

Distribusi frekuensi hasil tertinggi pada skor 73-76 sebesar $26,92 \%$.

\section{Kinerja Pegawai}

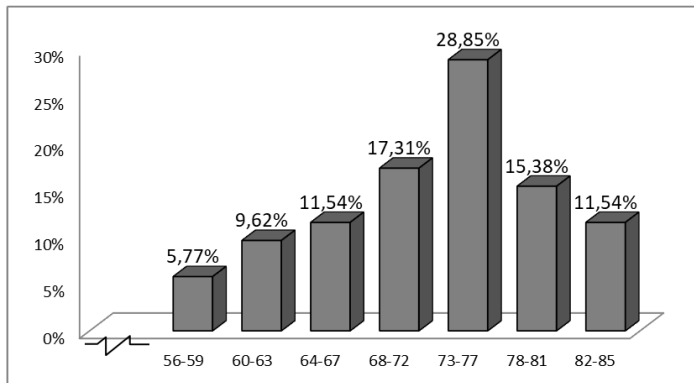

Distribusi frekuensi hasil tertinggi pada skor 73-77 sebesar $28,85 \%$.
5. Regresi Linier Berganda

$\mathrm{Y}=6,611+0.268 \mathrm{X}_{1}+0.371 \mathrm{X}_{2}$ $+0.440 \mathrm{X}_{3}+\mathrm{e}$

Dari persamaan tersebut dapat diperoleh nilai konstanta yang positif bernilai 6,611 yang menunjukkan bahwa jika nilai dari variabel bebas $\mathrm{X} 1, \mathrm{X} 2$, dan $\mathrm{X} 3$ sama dengan 0 maka nilai $\mathrm{Y}$ adalah 6,611 satuan.

a. Koefisien regresi variabel kompetensi adalah 0,268 yang menunjukkan jika ada peningkatan variabel kompetensi (X1) sebesar satu satuan maka akan menyebabkan kenaikan variabel kinerja pegawai sebesar 0,268 satuan dengan asumsi variabel lainnya konstan.

b. Koefisien regresi variabel motivasi adalah 0,371 yang menunjukkan jika ada peningkatan variabel motivasi (X2) sebesar satu satuan maka akan menyebabkan kenaikan variabel kinerja pegawai sebesar 0,371 satuan dengan asumsi variabel lainnya konstan.

c. Koefisien regresi variabel budaya organisasi adalah 0,440 yang menunjukkan jika ada peningkatan variabel budaya organisasi (X3) sebesar satu satuan maka akan menyebabkan kenaikan variabel kinerja pegawai sebesar 0,440 satuan dengan asumsi variabel lainnya konstan

6. Uji Hipotesis Statistik 
Tabel 1. Rekapitulasi Hasil Uji t

\begin{tabular}{|c|c|c|c|c|c|}
\hline No. & Variabel Pengujian & Kofisien $\beta$ & $t_{\text {hitung }}$ & $\begin{array}{c}t_{\text {tabel }} \\
(\alpha: 0,05)\end{array}$ & Keputusan \\
\hline 1 & $\mathrm{X}_{1}$ terhadap $\mathrm{Y}$ & 0,268 & 2,208 & 1,674 & Ha diterima \\
\hline 2 & $\mathrm{X}_{2}$ terhadap $\mathrm{Y}$ & 0,371 & 2,422 & 1,674 & Ha diterima \\
\hline 3 & $\mathrm{X}_{3}$ terhadap Y & 0,440 & 3,456 & 1,674 & Ha diterima \\
\hline
\end{tabular}

a. Pengaruh Kompetensi $\left(\mathrm{X}_{1}\right)$ terhadap Kinerja pegawai (Y)

Berdasarkan hasil pengujian menunjukkan koefisien variabel kompetensi terhadap kinerja pegawai dengan $\beta: 0,268$ dan nilai thitung 2,208. Berdasarkan nilai thitung $>$ ttabel maka koefisien $\beta$ signifikan atau dapat disimpulkan bahwa Ho ditolak dan $\mathrm{Ha}$ diterima yang berarti kompetensi $\left(\mathrm{X}_{1}\right)$ berpengaruh signifikan terhadap kinerja pegawai (Y).

b. Pengaruh Motivasi $\left(\mathrm{X}_{2}\right)$ terhadap Kinerja pegawai (Y) Berdasarkan hasil pengujian menunjukkan koefisien variabel motivasi terhadap kinerja pegawai dengan $\beta$ : 0,371 dan nilai thitung 3,422. Berdasarkan nilai thitung $>$ ttabel maka koefisien $\beta$ signifikan atau dapat disimpulkan bahwa Ho ditolak dan $\mathrm{Ha}$ diterima yang berarti motivasi $\left(\mathrm{X}_{2}\right)$ berpengaruh signifikan terhadap kinerja pegawai (Y)

c. Pengaruh Budaya organisasi(X3) terhadap Kinerja pegawai (Y) Berdasarkan hasil pengujian menunjukkan koefisien variabel budaya organisasi terhadap kinerja pegawai dengan $\beta$ : 0,440 dan nilai thitung 3,456 . Berdasarkan nilai thitung > ttabel maka koefisien $\beta$ signifikan atau dapat disimpulkan bahwa Ho ditolak dan Ha diterima yang berarti budaya organisasi (X3) berpengaruh signifikan terhadap kinerja pegawai (Y).

7. Uji F

Tabel 2. Output Uji F

\begin{tabular}{|c|c|c|c|c|c|c|}
\hline \multicolumn{7}{|c|}{ ANOVA $^{a}$} \\
\hline \multicolumn{2}{|c|}{ Model } & Sum of Squares & df & Mean Square & $\mathrm{F}$ & Sig. \\
\hline \multirow[t]{3}{*}{1} & Regression & 1724.245 & 3 & 574.748 & 20.711 & $.000^{6}$ \\
\hline & Residual & 1332.062 & 48 & 27.751 & & \\
\hline & Total & 3056.308 & 51 & & & \\
\hline
\end{tabular}

Berdasarkan hasil pengujian menunjukkan koefisien variabel kompetensi, motivasi dan Budaya organisasi terhadap kinerja pegawai dengan nilai Fhitung 20,711. Berdasarkan nilai Fhitung $>$ Ftabel (2,798) maka dapat disimpulkan bahwa Ho ditolak dan $\mathrm{Ha}$ diterima yang berarti kompetensi (X1) motivasi (X2), dan budaya organisasi (X3) berpengaruh signifikan terhadap kinerja pegawai (Y).

8. $\mathrm{R}^{2}$ Determinasi

Koefisien determinasi ( $\mathrm{R}$ square) 0,564. Hal ini berarti 
56,4\% variasi dari variabel $\mathrm{Y}$ dijelaskan oleh variasi dari k (X1, $\mathrm{X} 2, \mathrm{X} 3)$. Sedangkan sisanya $(100 \%-46,4 \%=53,6 \%)$ dipengaruhi oleh variabel lain di luar variabel-variabel yang diteliti.

\section{B. Pembahasan}

1. Pengaruh Kompetensi terhadap Kinerja pegawai

Berdasarkan hasil penelitian diperoleh hasil adanya pengaruh kompetensi terhadap kinerja pegawai. Koefisien yang dihasilkan bertanda positif yang menyatakan bahwa adanya pengaruh yang positif kompetensi dengan kinerja pegawai. Hal ini berarti jika kompetensi baik, maka kinerja pegawai juga akan meningkat. Hal ini sesuai dengan hipotesis yang menyatakan kompetensi memiliki pengaruh yang signifikan terhadap kinerja pegawai.

Kompetensi berpengaruh terhadap kinerja pegawai dimana kompetensi merupakan potensi pegawai untuk melaksanakan tugas/pekerjaan, efektifitas kerja individu, kepribadiaan dan pengetahuan, perilaku yang diperlukan dalam pelaksanaan tugas jabatanya yang meliputi motif, karakter, konsep diri, pengetahuan dan ketrampilan dari pegawai tersebut, dengan adanya potensi yang baik tersebut akan menunjang kinerja pegawai dalam melakukan tugas pekerjaanya.

$$
\text { Kompetensi merupakan }
$$

sebuah karakteristik dasar seseorang yang mengindikasikan cara berfikir, bersikap, dan bertindak serta menarik kesimpulan yang dapat dilakukan dan dipertahankan oleh seseorang pada waktu periode tertentu. Mereka juga mengatakan dari karakteristik dasar tersebut dapat mengetahui tingkat kompetensi atau standar kompetensi yang dapat mengetahui tingkat kinerja yang diharapkan dan mengkategorikan tingkat tinggi atau dibawah rata-rata. Oleh karena itu, penentuan ambang kompetensi tersebut sangat dibutuhkan dan penting sekali tentunya karena akan dapat dijadikan sebagai dasar pertimbangan bagi proses rekrutmen, seleksi, perencanaan, evaluasi kinerja, dan pengembangan sumber daya manusia lainnya. Pendapat ahli lainnya mengatakan bahwa kompetensi berhubungan dengan sikap, watak kepribadian, dan pengetahuan yang diperolehnya.

Temuan ini sesuai dengan hasil penelitian terdahulu oleh Triastity (2018) dengan judul Pengaruh Kompetensi, Motivasi, dan Budaya Organisasi Terhadap Kinerja Pegawai Di Kantor Wilayah Direktorat Jenderal Kekayaan Negara Jateng Dan Daerah Istimewa Yogyakarta dengan hasil bahwa kompetensi berpengaruh secara parsial dan simultan terhadap Kinerja Pegawai.

2. Pengaruh Motivasi terhadap Kinerja pegawai

Berdasarkan hasil penelitian diperoleh hasil adanya pengaruh motivasi terhadap kinerja pegawai, Koefesien regresi yang dihasilkan bertanda positif yang menyatakan bahwa ada pengaruh motivasi terhadap kinerja pegawai. Dengan melihat signifikasi variabel motivasi dapat disimpulkan bahwa motivasi memiliki pengaruh yang positif dan signifikan terhadap kinerja pegawai. Artinya jika 
motivasi semakin baik, maka kinerja pegawainya juga akan meningkat.

Motivasi berpengaruh terhadap kinerja pegawai dimana motivasi adalah dorongan dan keinginan, sehingga pegawai melakukan sesuatu kegiatan atau pekerjaan dengan memberikan yang terbaik demi tercapainya tujuan yang diinginkan. Tiap kegiatan yang dilakukan seseorang didorong oleh suatu kekuatan dari dalam diri orang tersebut, kekuatan pendorong inilah yang disebut motivasi. Motivasi adalah suatu kekuatan yang mengendalikan dan menggerakkan seseorang untuk melakukan tindakan atau perilaku yang diarahkan pada tujuan tertentu, seperti dikutip oleh Hariandja (2008: 85) yaitu manusia dimotivasi untuk memuaskan sejumlah kebutuhan yang melekat pada diri setiap manusia yang cenderung bersifat bawahan, dimana kebutuhan dapat didefinisikan sebagai suatu kesenjangan atau pertentangan yang di alami antara suatu kenyataan dengan dorongan yang ada dalam diri karyawan. Kebutuhan ini terdiri dari lima jenis dan terbentuk dalam suatu hierarki dalam pemenuhan. Motivasi merupakan masalah kompleks dalam organisasi, karena kebutuhan dan keinginan setiap anggota organisasi berbeda. Hal ini berbeda karena setiap anggota suatu organisasi adalah unit secara biologis maupun psikologis dan berkembang atas dasar proses belajar yang berbeda pula.

Temuan ini sesuai dengan hasil penelitian terdahulu oleh Bimo (2016), dengan judul
Pengaruh kompetensi, motivasi dan budaya organisasi terhadap kinerja karyawan pada Dinas Kebudayaan dan Pariwisata Kabupaten Probolinggo dengan hasil motivasi memiliki pengaruh terhadap kinerja pegawai.

3. Pengaruh Budaya organisasi terhadap Kinerja pegawai

Berdasarkan hasil penelitian diperoleh hasil adanya pengaruh budaya organisasi terhadap kinerja pegawai. Koefesien regresi yang dihasilkan bertanda positif yang menyatakan bahwa ada pengaruh positif budaya organisasi dengan kinerja pegawai. Dengan melihat signifikasi variabel budaya organisasi dapat disimpulkan bahwa budaya organisasi memiliki pengaruh yang positif dan signifikan terhadap kinerja pegawai. Artinya jika budaya organisasi baik, maka kinerja pegawai juga akan baik.

Budaya organisasi berpengaruh terhadap kinerja pegawai dimana budaya organisasi adalah suatu sistem nilai yang diperoleh dan dikembangkan oleh organisasi dan pola kebiasaan meliputi rasa hormat dan cara berperilaku, standar pekerjaan yang dilakukan, nilai-nilai utama dalam organisasi, kebijakan dalam organisasi, dan aturan dalam organisasi. Budaya organisasi dapat dilihat sebagai norma dari perilaku yang diharapkan. Nilainilai, filosofi, ritual, dan simbol, yang digunakan oleh para tenaga kerja. Budaya suatu organisasi juga mempengaruhi bagaimana memandang faktor eksternal pada budaya yang satu, kejadiankejadian di luar dipandang sebagai ancaman. Penerapan budaya organisasi adalah agar seluruh 
individu dalam perusahaan atau organisasi mematuhi dan berpedoman pada sistem nilai keyakinan dan norma-norma yang berlaku dalam perusahaan atau organisasi tersebut, (Mangkunegara, 2010: 63).

Budaya organisasi dapat tercermin diantaranya dari sistem yang meliputi besar kecilnya kesempatan berinovasi dan berkreasi bagi pegawai, pembentukan tim-tim kerja, kepemimpinan yang transparan dan tidak terlalu birokratis. Karakteristik tersebut yang dipersepsi oleh pegawai sebagai budaya organisasi, diharapkan dapat berfungsi dalam memberikan kepuasan kerja dan kinerja yang optimal dalam upaya mencapai tujuan organisasi.

Temuan ini sesuai dengan hasil penelitian terdahulu oleh Oktasari (2018), dengan judul Pengaruh Kompetensi, Budaya Organisasi dan Motivasi Terhadap Kinerja Pegawai Rumah Sakit Umum Daerah dengan hasil budaya organisasi berpengaruh positif dan signifikan terhadap kinerja pegawai.

\section{KESIMPULAN}

A. Kompetensi berpengaruh signifikan terhadap kinerja pegawai.

B. Motivasi pengaruh signifikan terhadap kinerja pegawai.

C. Budaya organisasi berpengaruh signifikan terhadap kinerja pegawai.

D. Kompetensi, motivasi, dan budaya organisasi secara simultan mempunyai pengaruh yang signifikan terhadap kinerja pegawai.

Berdasarkan angka coefisiensi dan nilai thitung maka dapat diketahui bahwa faktor yang paling berpengaruh terhadap kinerja pegawai adalah budaya organisasi.
DAFTAR PUSTAKA

Bimo. (2016). Pengaruh kompetensi, motivasi dan budaya organisasi terhadap kinerja pegawai pada Dinas Kebudayaan dan Pariwisata Kabupaten Probolinggo.

Eny, R. (2012). Perubahan Budaya Organisasi: Suatu Alternatif Strategi Menghadapi Masa Depan. Jurnal Bisnis dan Manajemen, Jakarta.

Gibson. (2008). Organisasi dan Manajemen: Perilaku, Struktur, Proses, Edisi Keempat. Jakarta: Erlangga.

Hariandja. (2008). Manajemen Sumber Daya Manusia. Jakarta: PT. Gramedia Widia Sarana Indonesia.

Hasibuan. (2009). Manajemen Sumber Daya Manusia. Jakarta: PT. Bumi Aksara.

Hasibuan. (2009). Manajemen: Dasar, Pengertian, dan Masalah Edisi Revisi. Jakarta: Bumi Aksara.

Mailinawati. (2014). Pengaruh Kompetensi dan Budaya Organisasi terhadap Motivasi Kerja dan Dampaknya pada Kinerja Pegawai Kantor Camat di Kabupaten Batu Barat. http://repository.ut.ac.id/2629/, 1(1), $21-24$.

Mangkunegara. (2009). Manajemen Sumber Daya Manusia Perusahaan. Bandung: PT. Rosda Karya.

Mathis., \& Jackson. (2006). Manajemen Sumber Daya Manusia Edisi Pertama. Jakarta: Salemba Empat.

Moeheriono. (2009). Pengukuran Kinerja Berbasis Kompetensi. Bogor: Ghalia.

Oktasari. (2018). Pengaruh Kompetensi, Budaya Organisasi dan Motivasi terhadap Kinerja Pegawai Rumah Sakit Umum Daerah. http://publikasi. mercubuana.ac.id/index.php/jimb/arti cle/view/3947, 4(1), 36 - 40.

Panggabean. (2007). Manajemen Sumber Daya Manusia. Bogor: Ghalia Indonesia. 
Prawirosentono. (2008). Kinerja \& Motivasi Pegawai (3rd ed.). Yogyakarta: BPFE.

Robbins. (2009). Perilaku Organisasi. Jakarta: Salemba Empat.

SANKRI. (2003). Sistem Administrasi Negara Kesatuan Republik Indonesia, Jakarta.

Schuller., \& Jackson dalam Direktory UPI. (2011). Manajemen Sumber Daya Manusia Menghadapi Abad Ke- 21 Edisi Ke-Enam. Jakarta: Erlangga.

Siagian. (2008). Manajemen Sumber Daya Manusia. Jakarta: PT. Bumi Aksara.

Sofyan. (2014). Pengaruh Motivasi Kerja, Budaya Organisasi dan Kompetensi Kerja terhadap Kinerja Pegawai di Bagian Keuangan SKPD Pemerintahan Provinsi Riau. https://media.neliti.com/media/public ations/33487-ID-pengaruh-motivasikerja-budaya-organisasi-dankompetensi-kerja-terhadapkinerja.pdf, 4(1), 23 - 27.

Sudarmanto. (2009). Kinerja dan Pengembangan Kompetensi SDM Teori, Dimensi dan Implementasi dalam Organisasi. Yogyakarta: Pustaka Pelajar.

Sudjana. (2005). Metoda Statistika. Bandung: Penerbit Tarsito.

Sugiyono. (2016). Statistika Untuk Penelitian. Bandung: Alfabeta.
Sugiyono. (2016). Metode Penelitian Manajemen. Bandung: Alfabeta.

Sunarto. (2007). Manajemen Pegawai. Yogyakarta: Amus.

Sutrisno. (2009). Manajemen Sumber Daya Manusia. Edisi Pertama. Cetakan Pertama. Jakarta: Penerbit Kencana.

Triastity. (2018). Pengaruh Kompetensi, Motivasi, dan Budaya Organisasi Terhadap Kinerja Pegawai Di Kantor Wilayah Direktorat Jenderal Kekayaan Negara Jateng Dan Daerah Istimewa Yogyakarta. http://garuda. ristekdikti.go.id/journal/view/5260?\& items $=10$ \& page $=16,2(1), 21-22$.

Waridin., \& Masrukhin. (2006). Pengaruh Motivasi Kerja, Kepuasan Kerja, Budaya Organisasi dan Kepemimpinan terhadap Kinerja Pegawai. Jurnal Ekonomi \& Bisnis, $7(2), 41-45$.

Wibowo. (2007). Manajemen Kinerja. Jakarta: PT. Raja Grafindo Parsada.

Sugiyono. (2010). Statistik untuk Peneltiian. Bandung: Alfabeta.

Sugiyono. (2016). Metode Penelitian Manajemen. Bandung: Alfabeta.

Tjiptono. (2001). Strategi Pemasaran. Edisi. Kedua. Cetakan Keenam. Yogyakarta: Penerbit Andy.

Tjiptono. (2008). Strategi Pemasaran, Edisi 3. Yogyakarta: Penerbit Andy. 